\title{
The Compressibility and Swell of Mixtures for Sand-Clay Liners
}

\author{
Muawia A. Dafalla \\ Bugshan Research Chair in Expansive Soils, Department of Civil Engineering, King Saud University, Riyadh 11421, Saudi Arabia
}

Correspondence should be addressed to Muawia A. Dafalla; mdafalla@ksu.edu.sa

Received 1 November 2016; Revised 1 January 2017; Accepted 13 March 2017; Published 10 April 2017

Academic Editor: Aboelkasim Diab

Copyright (C) 2017 Muawia A. Dafalla. This is an open access article distributed under the Creative Commons Attribution License, which permits unrestricted use, distribution, and reproduction in any medium, provided the original work is properly cited.

\begin{abstract}
Sand-clay liners utilize expansive clay to act as a filler to occupy the voids in the sand and thus reduce the hydraulic conductivity of the mixture. The hydraulic conductivity and transfer of water and other substances through sand-clay mixtures are of prime concern in the design of liners and hydraulic barriers. Many successful research studies have been undertaken to achieve appropriate mixtures that satisfy hydraulic conductivity requirements. This study investigates compressibility and swelling properties of mixtures to ensure that they were acceptable for light structures, roads, and slabs on grade. A range of sand-expansive clay mixtures were investigated for swell and compression properties. The swelling and compressibility indices were found to increase with increasing clay content. The use of highly expansive material can result in large volume changes due to swell and shrinkage. The inclusion of less expansive soil material as partial replacement of bentonite by one-third to two-thirds is found to reduce the compressibility by $60 \%$ to $70 \%$ for $10 \%$ and $15 \%$ clay content, respectively. The swelling pressure and swell percent were also found significantly reduced. Adding less expansive natural clay to bentonite can produce liners that are still sufficiently impervious and at the same time less problematic.
\end{abstract}

\section{Introduction}

The demand for liners in environmental and containment projects is growing [1]. Sand-clay liners utilize highly plastic bentonite clay to act as a barrier and fill the voids in the sand and thus reduce the hydraulic conductivity of the mixture. The use of bentonite can result in large volume changes as a result of swell and shrinkage. In order to improve compressibility and swell it is suggested to add a portion of clay with less plasticity than bentonite. This is expected to produce sufficiently impervious liner with less compressibility and less potential for expansion leading to utilizing the natural local clays of less plasticity in liners and thus reducing the demand for bentonite and improving the liner performance. The purpose of this paper is to investigate the influence of adding natural clay soils on the compressibility and swell. Dafalla and Al-Mahbashi [2] investigated the effect of adding natural clay to bentonite on the water retention curve of sand-bentonite mixtures. This study is focused on the use of expansive clay as part of sand-clay liners in geoenvironmental projects. The work carried out in this research is part of a project financed by NPST (National Plan for Science and
Technology, Saudi Arabia) to investigate using local clays in liners in eastern parts of Saudi Arabia.

\section{Background}

2.1. Expansive Soils and Their Use. Extensive research work has been carried out on expansive soils as they are a serious hazard to buildings and light structures due to their volume changes when subject to moisture content alterations causing movement of these structures. The behaviour of such clays when subjected to moisture changes is controlled by some intrinsic and external factors. The intrinsic factors include the type of clay (mineralogy and chemical equilibrium), density and packing state, initial moisture content, pore water pressure, and pore air pressure, while the external factors include vertical and horizontal stresses, the source of moisture, hydraulic gradient, and rate at which water is introduced in addition to the chemistry of the water. Many of these factors are interrelated [3].

Expansive soils, sometimes known as black cotton soil [4], are good for agriculture due to the level of nutrients and minerals they contain. This clay is also used in medical 
products and used extensively in cosmetics. Clay nanocomposite studies for producing materials of enhanced performance are currently attracting the attention of many researchers [4].

2.2. Sand-Clay Mixtures. Naturally occurring sand-clay soils are not usually efficient for the intended purpose of, or usage as, impermeable liners. Geotechnical and geoenvironmental engineers have found it necessary to devise an engineering approach to achieve the appropriate hydraulic conductivity and other required properties. The sand-clay liners can also control the movement of other materials and toxic pollutants due to their low permeability and ionic absorption properties. The optimum ratio of clay to sand depends mainly on the porosity of the granular material. Compacted sand-clay mixtures were introduced to act as barriers in waste disposal following increased awareness and rising environmental concerns during the second half of the twentieth century [1]. The control of waste leachate can be contained using liners of low hydraulic conductivity [5].

The sand-clay mixtures are commonly used as liners in waste disposal and in the protection of strategic power projects. Designs using bentonite have been found successful in many applications. The cost of processed clay and bentonite prompted many researchers to investigate the use of local materials. Rawas et al. (2005) investigated the use of Oman shale in liners. Obrike et al. [6] investigated the use of Auchi Shale and Imo shale in waste disposal landfills in Nigeria. Langdon et al. [7] studied the permeability of clay liners of the same geological formation and different depositional basins in Turkey. These are only examples and other research is currently going on.

Geosynthetic material can also be used in combination with sand-clay liners. The ASTM standards introduced a new test to determine the hydraulic conductivity values [8] which describes the laboratory measurement of both flux and hydraulic conductivity of GCL-specimens utilizing a flexible wall permeameter.

2.3. Literature Review on the Compressibility of Sand-Clay Mixtures. The compressibility and swell nature of sand-clay mixtures is of great importance. Highly expansive material can expand to a stage that is likely to cause excessive distortion to surfaces or provide an uneven support for foundations and light structures. The response to loads and stresses on sand-clay mixtures has been studied by many researchers. Wasti and Alyanak [9] studied sand-clay mixtures and observed that when the initial, unswelled, clay content is sufficient to fill the voids within the sand at its maximum porosity, the overall behaviour tends to be similar to clay. The influence of the clay material on the overall behaviour of soil mixtures has been raised by many researchers (e.g., [1012]). Tsotsos et al. [13] introduced a new experimental and numerical concept to deal with mixed soils. They concluded that deformational behaviour of mixed soils depends strongly on the percentage of clay in the mixture and the mechanical properties of each component. The modelling approach was based on the behaviour of well-defined types of structures.
This is unlikely to work for all mixtures or for variable ranges and types of sand-clay mixtures.

The factors, including placement conditions, affecting swelling in bentonite and other clays are also the same factors affecting sand-clay mixtures. Dafalla [14] discussed the role of initial moisture content and dry density on the behaviour of clays. Dixon [15] worked on the swelling behaviour of bentonite based backfill used for nuclear structures in Canada. He showed that swelling pressure increases with the increase of effective clay dry density.

Research on sand-clay mixtures in semiarid areas, however, has been limited. Dafalla [3] presented a model for predicting the behaviour of artificial sand-clay mixtures using the fall cone testing method. Alawaji [16] studied the swell and compressibility characteristics of sand-bentonite mixtures wetted with liquids with two types of commercial bentonite and investigated the compressibility behaviour when the mixture is subjected to liquids with variable concentrations of $\mathrm{Ca}\left(\mathrm{NO}_{3}\right)_{2}$ and $\mathrm{NaNO}_{3}$. Alawaji [16] used these chemicals to investigate their influence on the process of swelling and compressibility. His results indicated that swell potential (SP), swell time, swell pressure, and volume compressibility decrease with the increase in chemical concentrations. Mollins et al. [17] found that the compaction method does not affect the final clay void ratio of the tested samples. Benson and Boutwell [18] investigated compaction conditions and scale dependent hydraulic conductivity of compacted clay liners.

Phanikumar et al. [19] conducted compressibility and swell tests for clay-sand mixtures and concluded that as the sand content in the blends increased from $0 \%$ to $30 \%$, swell potential decreased by $71 \%$ and $50 \%$ and swelling pressure decreased by $67 \%$ and $57 \%$, respectively, for soil fractions passing the $425 \mu \mathrm{m}$ and $75 \mu \mathrm{m}$ sieve. They also stated that the coefficient of volume compressibility reduced by $30 \%$ and compression index decreased by $50 \%$ as the sand content increased from $0 \%$ to $30 \%$ for soil fractions passing the $425 \mu \mathrm{m}$ sieve.

The main objective of this study is to examine the compression and swell of sand-expansive clay liners in order to help designers to optimize and select the appropriate mix. Use of clay mixtures consisting of natural clay and commercial bentonite instead of only bentonite in sand-clay mixtures is investigated as a new approach to produce a less problematic and more economical mixes. This is considered to be a significant problem in semiarid areas where significant drying of these mixes may occur and lead to cracking.

\section{Materials and Test Methods}

Natural clay materials of high plasticity are abundant in many semiarid regions. The properties of most of these clays do not satisfy the requirements for use in sand-clay liners. This can be attributed to low plasticity or failure to provide the required hydraulic conductivity. It was decided to investigate utilizing these materials in reducing the amount of processed bentonite and enhancing the shrink-swell properties of sandclay liners. Al-Qatif clay in Saudi Arabia is believed to have good potential as an additive to enhance the performance 
TABLE 1: Physical properties of Al-Qatif clay.

\begin{tabular}{lc}
\hline Property & Range \\
\hline Material passing sieve number 200 & $>90 \%$ \\
Liquid limit & $130-150$ \\
Plastic limit & $60-70$ \\
Plasticity index & $70-80$ \\
Maximum dry density & $1.150-1.200 \mathrm{gm} / \mathrm{cm}^{3}$ \\
Optimum moisture Content & $32-40 \%$ \\
Swell percent (ASTM D4546) & $16-18 \%$ \\
Swelling pressure (ASTM D4546) & $500-800 \mathrm{kN} / \mathrm{m}^{3}(\gamma=$ \\
\end{tabular}

of sand-clay liners. Commercial bentonite and Al-Qatif clay were chosen to study the swell and compressibility properties of selected sand-clay liners.

3.1. Al-Qatif Clay. The unprocessed, natural expansive clay used in this research was obtained from the city of AlQatif located on the Arabian Gulf shoreline $400 \mathrm{~km}$ from Riyadh, the capital of Saudi Arabia. Several researchers have investigated the swelling characteristics of Al-Qatif expansive clay [20-22]. Based on these investigations, Al-Qatif clay is typically characterized as highly expansive soil due to its high montmorillonite mineral content. Soil samples were obtained from open pits excavated to a depth of $1.5-3.0 \mathrm{~m}$ below ground surface. Samples were transferred to the laboratory and complete geotechnical characterization and chemical composition were performed. Shamrani et al. [23] indicated that natural Al-Qatif clay is characterized among problematic clays due to its high plasticity. A summary of geotechnical characterization results is presented in Table 1. Chemical composition of Al-Qatif clay is presented in Table 2.

3.2. Sand. Sand used in this study was commercially available uniform sand that is locally used in concrete mixes in Riyadh. It is typically known as "concrete sand" and is abundant in Saudi Arabia. The grain size ranges from 0.6 to $0.1 \mathrm{~mm}$. According to the Unified Soil Classification System (USCS, [24]), this sand is classified as poorly graded sand (SP).

3.3. Bentonite. The bentonite used in this study was HY OCMA obtained from a local supplier. The index properties of HY OCMA bentonite used in the present study are given in Table 3. The chemical composition of bentonite is given in Table 4.

\subsection{Sand-Clay Mixture Preparation and Compaction Tests}

3.4.1. Sample Preparation. Samples of Al-Qatif expansive clay obtained from the field were air dried, pulverized, and sieved using sieve size $425 \mu \mathrm{m}$ (number 40 ). The oven dried sand and Al-Qatif clay were mixed thoroughly and then the required water content was added and mixed in and the sample stored in plastic bags for 24 hours to mature. Sandbentonite clay mixes were prepared in a similar way.

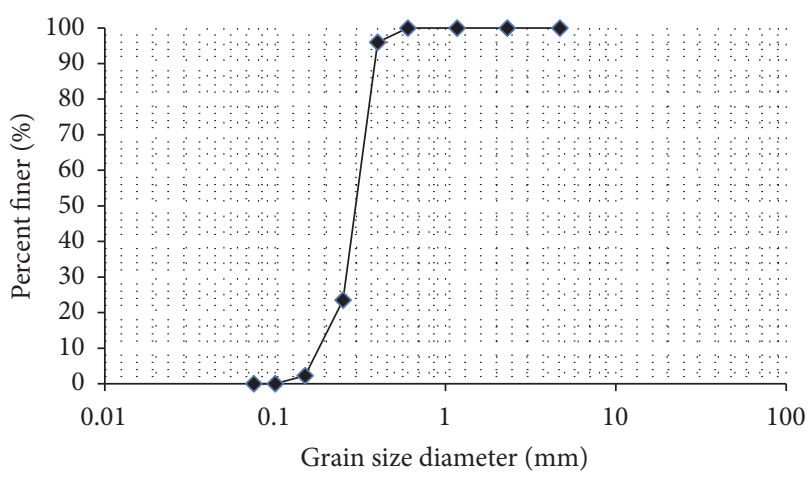

Figure 1: Grain Size distribution of the uniform sand used in this research.

3.4.2. Compaction Tests. Compaction tests were carried out to assess the optimum water contents and maximum dry unit weights of sand-Al-Qatif expansive clay mixtures and sandbentonite mixtures. Al-Qatif expansive clay contents used were $0 \%, 5 \%, 10 \%, 15 \%, 20 \%$, and $25 \%$ by dry weight of sand and the bentonite contents used were $0 \%, 5 \%, 10$, and $20 \%$ by dry weight of sand. The mix proportions quoted are for clays in the air dried state. For each mixture, the optimum water content and the maximum dry unit weight were determined using standard Proctor compaction method (ASTM D698 [25], method A). Samples of mixtures were prepared with water contents ranging from 3 to $22 \%$. Distilled water was added to the mixtures to obtain the desired water contents.

A $2.5 \mathrm{~kg}(5.5 \mathrm{lb})$ hammer was used to compact the mixtures into the $101.6 \mathrm{~mm}$ ( $4 \mathrm{in}$ ) mold (inside diameter) with $113.9 \mathrm{~mm}$ ( $4.5 \mathrm{in}$ ) in height in order to ensure the uniform compaction for each layer. Three layers were compacted in each mold. After compaction and leveling, the weight of the compacted mixtures was determined along with their water contents. The maximum dry unit weight and optimum water content of the compacted sand-expansive clay and compacted sand-bentonite mixtures were determined from the compaction curve. The sand gradation and porosity are prime factors in designing sand-clay mixtures. Figure 1 presents grain size distribution of the uniform sand used in this research. Figure 2 presents the maximum dry density at optimum moisture content for Al-Qatif clay-sand mixtures. Addition of $5 \%, 10 \%$, and $12 \%$ bentonite to the sand was found to shift the maximum dry density to $17.7,18.2$, and $18.5 \mathrm{kN} / \mathrm{m}^{3}$ and the optimum moisture content to 11,11 , and 12 percent. Figure 3 presents the maximum dry density and optimum moisture content for the selected clay-sand mixtures used in this study.

3.5. Compressibility and Swell Testing. One-dimensional consolidation and swelling tests were carried out using conventional oedometer methods. The fixed ring apparatus is an oedometer in which the ring holding the sample is not allowed to move during testing. A chamber surrounding the ring is used for submergence of the sample. Two porous disks with Whatman filter papers next to the sample were placed at the bottom and top of the sample. The oedometer cell was 
TABLE 2: Chemical composition of Al-Qatif clay.

\begin{tabular}{lccccccc}
\hline $\mathrm{K}^{+}(\%)$ & $\mathrm{K}_{2} \mathrm{O}(\%)$ & $\mathrm{Al}(\%)$ & $\mathrm{Al}_{2} \mathrm{O}_{3}(\%)$ & $\mathrm{Si}(\%)$ & $\mathrm{SiO}_{2}(\%)$ & $\mathrm{Ca}^{2+}(\%)$ & $\mathrm{CaO}^{2}(\%)$ \\
\hline 1.8 & 2.2 & 3.3 & 6.3 & 8.1 & 17.3 & 0.7 & 0.9 \\
\hline
\end{tabular}

TABle 3: Properties of HY OCMA bentonite.

\begin{tabular}{lc}
\hline Property & Value \\
\hline Specific gravity, GS & 2.76 \\
Liquid limit, LL (\%) & 480 \\
Plastic limit, PL (\%) & 49.6 \\
Plasticity index, PI (\%) & 430 \\
\hline
\end{tabular}

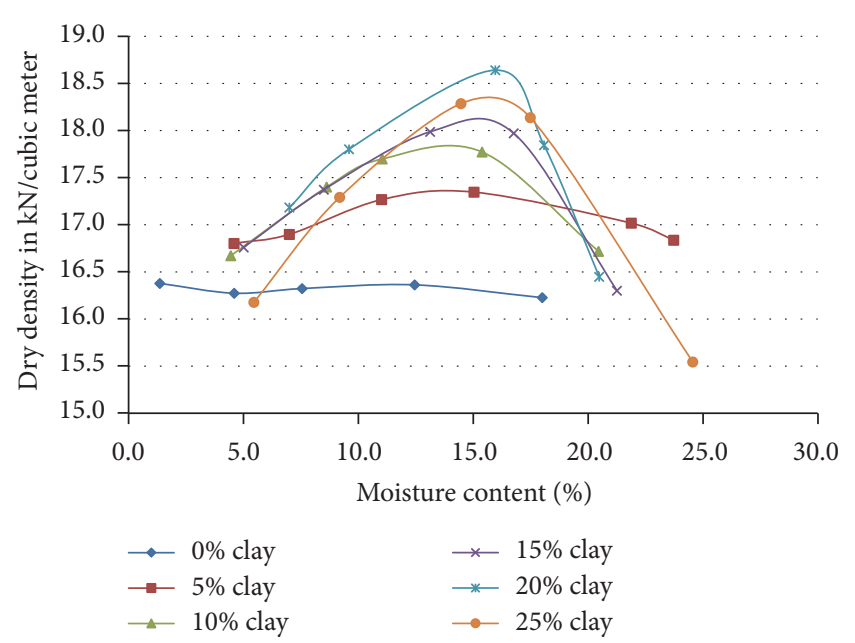

FIgURE 2: Dry density versus moisture content for Al-Qatif claysand mixtures.

placed within a loading frame, which transmits vertical loads through a specially designed lever arm. A dial gauge of an accuracy of $0.01 \mathrm{~mm}$ was used to monitor the change of the sample height. Digital dial gauges connected to a data logger were used in some of the experiments. Front loading frames were used for most of the tests. The diameter of the ring used was $50 \mathrm{~mm}$.

The one-dimensional swell testing method used for determining swell potential was carried out in accordance with ASTM D4546-96 [26] (method A). The variation from this method was the use of a seating pressure of $7 \mathrm{kN} / \mathrm{m}^{2}$. In this method the sample was wetted and allowed to swell vertically at the seating pressure until primary swell was complete.

The oedometer tests performed on samples of expansive clay, bentonite powder, or mixtures were carried out using a similar approach. The amount of soil needed to fill up the consolidation ring is worked out when the dry density is known. The calculated amount is placed in three lifts in the ring using hand tamping. The samples prepared were placed in the oedometer ring and leveled off prior to placement in the oedometer cell. The weights of the ring and the sample were determined. The initial height of the sample was recorded. The initial moisture content and specific gravity

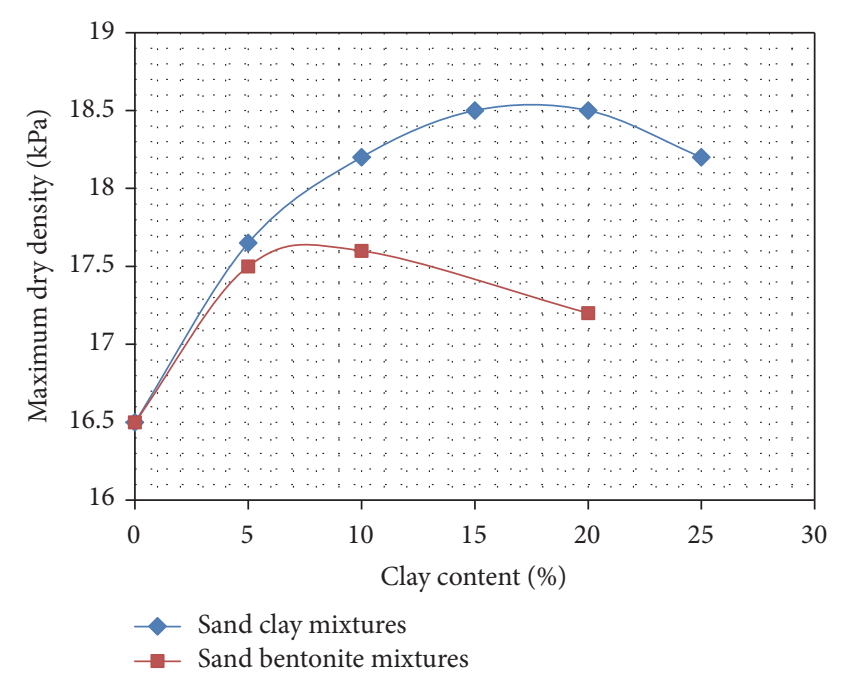

FIGURE 3: Maximum dry density-clay content relationships of sandclay mixtures and sand-bentonite mixtures.

were obtained. These measures enabled the height of solids, $\mathrm{Hs}$, to be computed.

\section{Test Program}

The test program included testing three clay mixtures described as A, B, and C. Mixture referred to as (Form A) clay is commercial bentonite without any addition of Al-Qatif clay. This gives a typical sand-bentonite mixture as used in practice. For this mixture, clay contents were 5,10 , and $15 \%$ by weight of sand. The tests for Form A were carried out at a dry density of $17.5 \mathrm{kN} / \mathrm{m}^{3}$. Swell and compressibility properties of these mixtures were used as reference for the other mixtures. Mixture referred to as (Form B) is a clay mixture of commercial bentonite and Al-Qatif clay in which one-third is bentonite and two-thirds are AlQatif clay. Mixture referred to as (Form C) is a mixture in which two-thirds are bentonite and one-third is Al-Qatif clay. These ratios are based on air dried weights. The initial dry densities for Forms B and C were the maximum dry density obtained from the compaction tests. Moisture contents at the optimum moisture content were selected. These selections were made because the liner material on site is normally compacted to approximately the maximum dry density and optimum moisture content by the contractors. Variations of $+/-2 \%$ moisture are normally acceptable and $95 \%$ level of compaction is also accepted.

For Form B and Form C, total clay contents of 5, 10, 15, 20, 25 , and $30 \%$ were tested for swell and compressibility. A total of 12 samples were tested for these two forms. Each sample is represented by two specimens. Three samples were tested 
TABLE 4: Typical chemical composition of OCMA grade bentonite.

\begin{tabular}{lccccccc}
\hline $\mathrm{FeO}_{3}(\%)$ & $\mathrm{K}_{2} \mathrm{O}(\%)$ & $\mathrm{Na}_{2} \mathrm{O}(\%)$ & $\mathrm{Al}_{2} \mathrm{O}_{3}(\%)$ & $\mathrm{MgO}(\%)$ & $\mathrm{SiO}_{2}(\%)$ & $\mathrm{TiO}_{2}(\%)$ & $\mathrm{CaO}(\%)$ \\
\hline 2.9 & 0.1 & 1.9 & 17.0 & 4.6 & 55.2 & $<0.1$ & 0.9 \\
\hline
\end{tabular}

Source Ore-Arabian Gulf Region-OCMA Grade.

TABLE 5: Data of swell percent and swelling pressure for the bentonite sand mixtures.

\begin{tabular}{|c|c|c|c|c|c|c|c|c|}
\hline Clay content & Mixture Form & $\mathrm{Cc}$ & Cs & $e_{o}$ & Swell \% & Swell pressure $\mathrm{kN} / \mathrm{m}^{2}$ & Dry density $\mathrm{kN} / \mathrm{m}^{3}$ & m.c \\
\hline $5 \%$ (S R1) & Form A & 0.0362 & - & 0.5167 & 1.55 & 95 & 1.75 & 0 \\
\hline $10 \%(\mathrm{~S} R 2)$ & Form A & 0.0986 & - & 0.5182 & 4.57 & 175 & 1.75 & 0 \\
\hline $15 \%$ (S R3) & Form A & 0.1883 & - & 0.5198 & 8.23 & 200 & 1.75 & 0 \\
\hline
\end{tabular}

for the bentonite mixtures (Form A). The main parameters measured in these tests include the swell percent, the swelling pressure, the compressibility index, and the swelling index. The initial void ratio was reported for each test.

Swell and compressibility data and plots for Forms A, $\mathrm{B}$, and C clays were constructed and compared. Trends and behaviour as shown by test results should provide information about the general behaviour and a guide to select the most reliable mixture for the intended liner.

\section{Results and Discussion}

5.1. Moisture-Dry Density Relationship. The main reason for adding clay is to reduce the mixture permeability. Adding too little clay will result in an unacceptable high permeability and may result in the fines washing away when subjected to water flow under significant hydraulic gradients. As part of this study, moisture-density relationships were investigated for the sand-clay mixtures. The maximum dry density is found to increase with the increase of clay content up to a certain limit and then decreases. This is due to more fines replacing sand grains when the voids are fully occupied. At the optimum moisture content the degree of saturation is less than $100 \%$ due to air voids present in the system. The compacted soil is a three-phase system consisting of air, water, and solids. A clay paste formed within the pores can expand and fill up all air spaces when $100 \%$ impervious mixture is to be attained. Figure 3 presents moisture-density relationships of sand-clay mixtures and sand-bentonite mixtures. From Figure 2 it can be seen that $15 \%$ clay is just enough to fill up the voids at the optimum moisture content. Smaller amount of clay can still fill up the voids provided that enough expansion can be generated due to moisture increase beyond the optimum moisture content. In semiarid areas it is advisable to consider less expansive material as dry seasons may result in shrinkage and cracking. Clays of high plasticity can result in high linear shrinkage and expected to produce severe cracking in the field. For bentonite mixes it can be seen that less than $15 \%$ can fill up the gaps of the sand. In fact $5 \%$ or little more can be sufficient to fill the gap when the clay is fully saturated.

\subsection{Compressibility and Swell of Sand-Bentonite Mixtures.} Three different bentonite contents were considered to investigate the compressibility and swell of sand-bentonite mixtures. The tests were carried out on initially dry mixtures

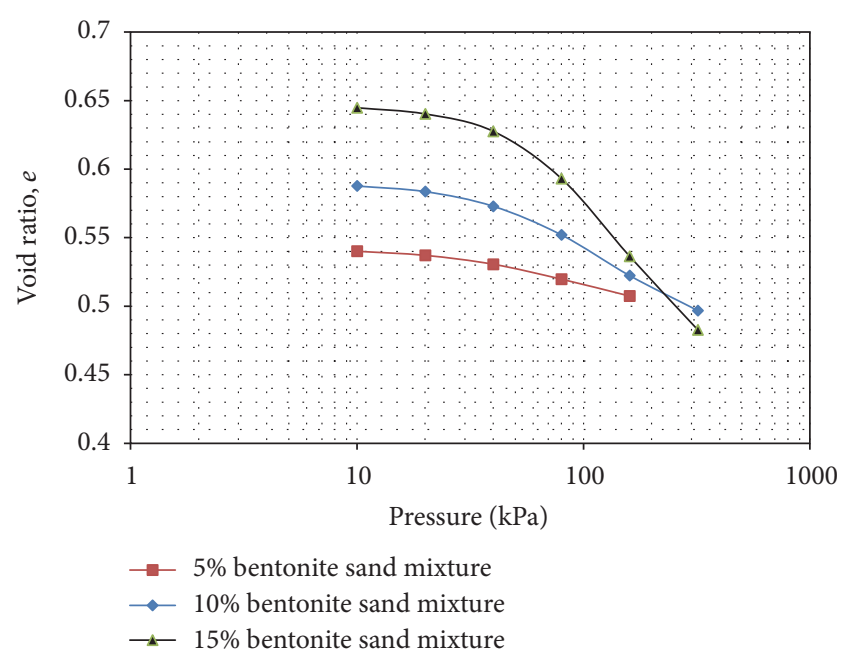

FIGURE 4: Void ratio versus log pressure curves for sand-bentonite mixtures.

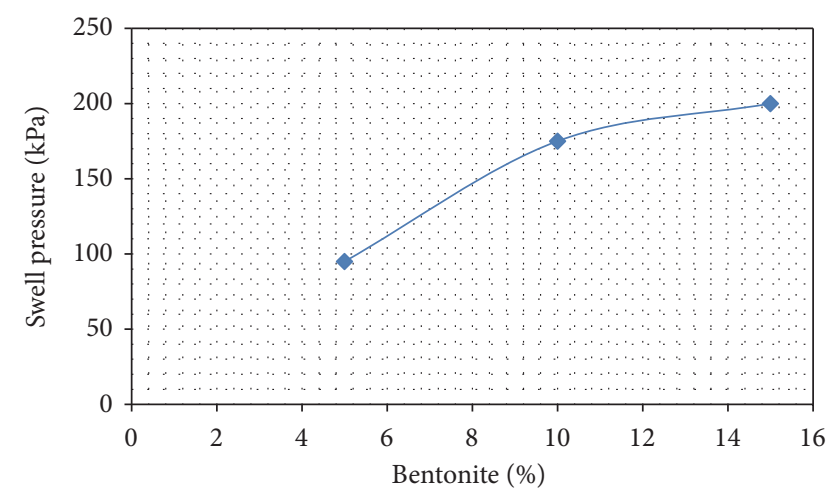

FIGURE 5: Swelling pressure for different bentonite contents in the mixture.

compacted to densities close to the maximum dry density and void ratios. Table 5 and Figures 4, 5, and 6 present the compressibility, swell pressure, and swell percent profiles for the sand-bentonite mixtures tested. The swelling pressure and swell percent indicated a clear increase with increase. The compressibility index is high for higher bentonite content. 
TABLE 6: Summary of swell and compression data for Form B clay.

\begin{tabular}{|c|c|c|c|c|c|c|c|c|}
\hline Clay content & $\begin{array}{c}\text { Mixture } \\
\text { form }\end{array}$ & $\begin{array}{c}\text { Compression } \\
\text { index Cc }\end{array}$ & $\begin{array}{c}\text { Swell index } \\
\text { Cs } \\
\end{array}$ & Void ratio $e_{o}$ & Swell \% & Swell pressure $(\mathrm{kPa})$ & $\begin{array}{c}\text { Dry density } \\
\mathrm{kN} / \mathrm{m}^{3}\end{array}$ & $\begin{array}{c}\text { m.c. } \\
\%\end{array}$ \\
\hline $5 \%(S 1-a)$ & Form B & 0.0179 & - & 0.5167 & 0.20 & 17 & 17.5 & 0 \\
\hline $5 \%(\mathrm{~S} 1-\mathrm{b})$ & Form B & 0.0374 & 0.0126 & 0.4911 & 0.00 & 0 & 17.8 & 11 \\
\hline $10 \%(\mathrm{~S} 3-\mathrm{a})$ & Form B & 0.0392 & - & 0.5198 & 1.67 & 70 & 17.5 & 0 \\
\hline $10 \%(\mathrm{~S} 3-\mathrm{b})$ & Form B & 0.0492 & 0.0159 & 0.4620 & 0.51 & 11 & 18.2 & 11 \\
\hline $15 \%(S 5-a)$ & Form B & 0.0734 & - & 0.5198 & 3.83 & 100 & 17.5 & 0 \\
\hline $15 \%(S 5-b)$ & Form B & 0.0377 & 0.0154 & 0.4706 & 2.17 & 50 & 18.1 & 13 \\
\hline $20 \%($ S7 -a) & Form B & 0.0754 & 0.0277 & 0.4404 & 6.16 & 85 & 18.5 & 13 \\
\hline $20 \%(S 7-b)$ & Form B & 0.0447 & 0.0183 & 0.4423 & 7.23 & 100 & 18.5 & 13 \\
\hline $25 \%(S 9-a)$ & Form B & 0.0691 & 0.0223 & 0.4739 & 6.43 & 90 & 18.1 & 17 \\
\hline $25 \%(\mathrm{~S} 9-\mathrm{b})$ & Form B & 0.0497 & 0.0199 & 0.4730 & 5.15 & 60 & 18.1 & 17 \\
\hline $30 \%($ S11 -a) & Form B & 0.0860 & 0.0297 & 0.5096 & 11.30 & 170 & 17.7 & 16 \\
\hline $30 \%$ (S11 -b) & Form B & 0.0726 & 0.0202 & 0.5102 & 11.44 & 150 & 17.7 & 16 \\
\hline
\end{tabular}

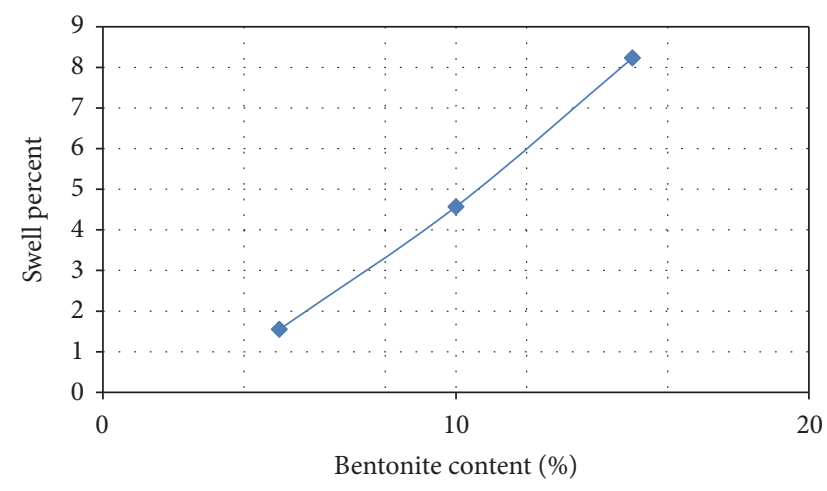

Figure 6: Swelling percent for different bentonite contents in the mixture.

5.3. Compressibility and Swell of Mixtures of Bentonite and Natural Clay (1:2 Ratio). This section discusses material described as Form B in which the clay added to the sand is composed of one-third bentonite and two-thirds Al-Qatif expansive clay. The overall clay content by weight of sand was in the range $5 \%$ to $30 \%$. Table 6 presents summary of data obtained for the combination of bentonite and natural clay (1:2 ratio).

Figure 7 presents void ratio versus the semilogarithm of pressure for $5 \%$ and $25 \%$ Form B added clay. This data was selected as typical representation of the general behaviour. The swell percent is negligible for 5\% clay and equals $5.15 \%$ for the $25 \%$ clay. The compressibility is much higher for $25 \%$ clay and this is reflected by the steeper slope shown for different loading stages. The swelling pressure and the swell percent are plotted for all Form B clay ratios in Figures 8 and 9. The swelling pressure for $5 \%, 10 \%$, and $15 \%$ was obtained for samples of different initial moisture content and this is reflected in the wider variation of the results.

5.4. Compressibility and Swell of Mixtures with Bentonite and Natural Clay (2:1 Ratio). This section discusses material

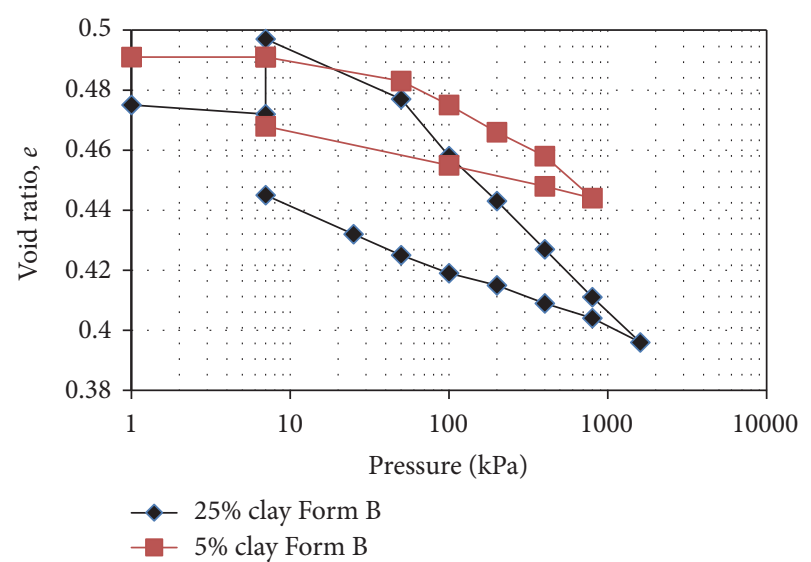

FIGURE 7: Swell-compressibility profiles for two selected clay ratios of Form B clay.

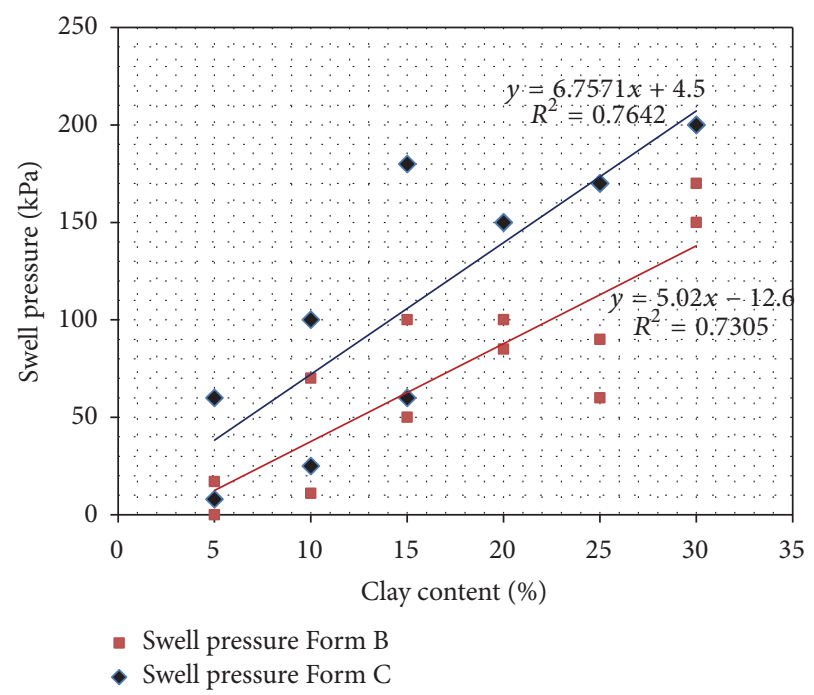

FIGURE 8: Swelling pressure of sand-clay mixtures. 
TABLE 7: Summary of swell and compression data for Form C clay.

\begin{tabular}{|c|c|c|c|c|c|c|c|c|}
\hline Clay content & $\begin{array}{c}\text { Mixture } \\
\text { form }\end{array}$ & $\begin{array}{c}\text { Compression } \\
\text { index Cc }\end{array}$ & $\begin{array}{c}\text { Swell index } \\
\text { Cs } \\
\end{array}$ & Void ratio $e_{o}$ & Swell \% & Swell pressure $(\mathrm{kPa})$ & $\begin{array}{c}\text { Dry density } \\
\mathrm{kN} / \mathrm{m}^{3}\end{array}$ & $\begin{array}{c}\text { m.c. } \\
\%\end{array}$ \\
\hline $5 \%(S 2-a)$ & Form C & 0.0275 & - & 0.5167 & 0.92 & 60 & 17.5 & 0 \\
\hline $5 \%(\mathrm{~S} 2-\mathrm{b})$ & Form C & 0.0347 & 0.0141 & 0.4925 & 0.24 & 8 & 17.8 & 11 \\
\hline $10 \%(\mathrm{~S} 4-\mathrm{a})$ & Form C & 0.0438 & - & 0.5198 & 1.91 & 100 & 17.5 & 0 \\
\hline $10 \%(\mathrm{~S} 4-\mathrm{b})$ & Form C & 0.0392 & 0.0114 & 0.4620 & 2.26 & 25 & 18.2 & 11 \\
\hline $15 \%(S 6-a)$ & Form C & 0.0721 & - & 0.5198 & 4.48 & 180 & 17.5 & 0 \\
\hline $15 \%(\mathrm{~S} 6-\mathrm{b})$ & Form C & 0.0352 & 0.0219 & 0.4706 & 4.09 & 60 & 18.1 & 13 \\
\hline $20 \%($ S8 -a) & Form C & 0.0718 & 0.0274 & 0.4417 & 10.80 & 150 & 18.5 & 13 \\
\hline $20 \%($ S8 -b) & Form C & 0.0573 & 0.0209 & 0.4490 & 18.15 & 150 & 18.5 & 13 \\
\hline $25 \%(\mathrm{~S} 10-\mathrm{a})$ & Form C & 0.0666 & 0.0127 & 0.4739 & 13.19 & 170 & 18.1 & 17 \\
\hline $25 \%(\mathrm{~S} 10-\mathrm{b})$ & Form C & 0.0605 & 0.0206 & 0.4773 & 16.56 & 170 & 18.1 & 17 \\
\hline $30 \%(\mathrm{~S} 12-\mathrm{a})$ & Form C & 0.1370 & 0.0302 & 0.5569 & 34.74 & 200 & 17.7 & 16 \\
\hline $30 \%(\mathrm{~S} 12-\mathrm{b})$ & Form C & 0.0870 & 0.0249 & 0.5523 & 28.11 & 200 & 17.7 & 16 \\
\hline
\end{tabular}

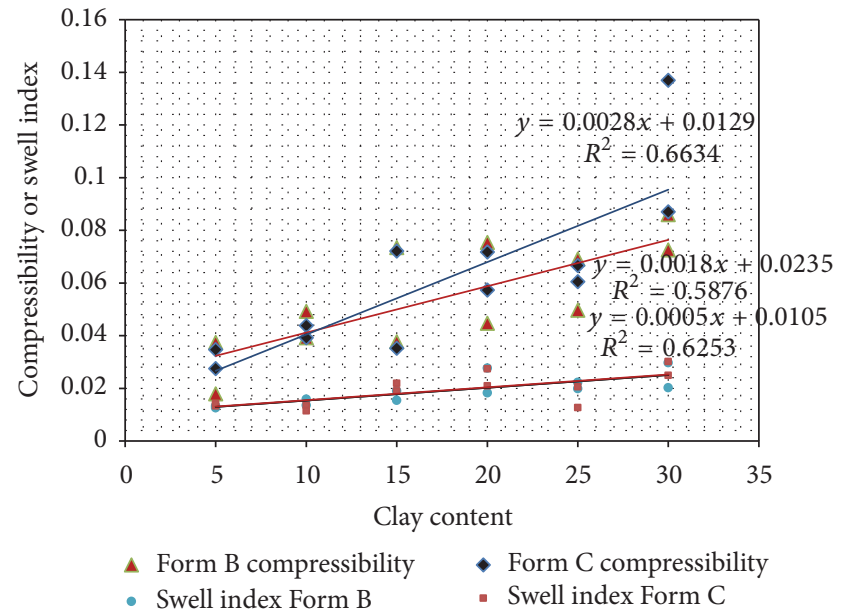

FIGURE 9: Swelling percent of sand-clay mixtures.

described as Form $\mathrm{C}$ in which the clay added to the sand is composed of two-thirds bentonite and one-third Al-Qatif expansive clay. Overall clay content by weight of sand was in the range of $5 \%$ to $30 \%$. The samples were subjected to swell and compression tests using oedometers. Table 7 presents summary of data obtained for the combination of bentonite and natural clay $(2: 1$ ratio).

The selected, typical ratios of clay mixtures shown in Figure 10 demonstrate that the compressibility of bentonite rich material is high when compared to the other less expansive mixtures. The compressibility index at an intermediate point $(15 \%)$ can be taken as 0.045 . Figure 11 provides an overall view of compressibility index and swell index for all mixtures tested regardless of the type of clay used.

The compressibility index can be predicted based on the general clay content for the two proposed forms using the equation

$$
\begin{aligned}
& \mathrm{Cc}=0.0018 \mathrm{CL}+0.024(\text { Form } \mathrm{B}) \\
& \mathrm{Cc}=0.0028 \mathrm{CL}+0.013(\text { Form } \mathrm{C}),
\end{aligned}
$$

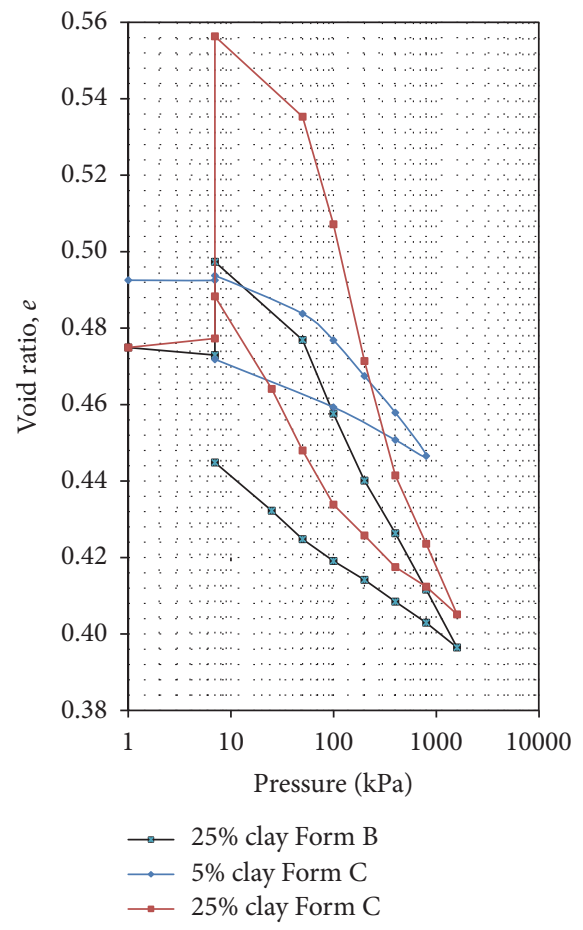

FIGURE 10: Swell-compressibility profiles for selected ratios (25\% of Form C and 25\% of Form B clay compared to 5\% clay Form C).

where $\mathrm{Cc}$ is the compressibility index and CL is the clay content expressed as percentage.

The swelling index, Cs, can similarly be predicted using the equation

$$
\mathrm{Cs}=0.0005 \mathrm{CL}+0.011 \text { (Form B and Form C). }
$$

This suggests that variation in swell index is negligible for the two tested forms.

Swelling pressure and swell percent for Form $\mathrm{C}$ values are plotted in Figures 8 and 9. The higher percentage of bentonite 


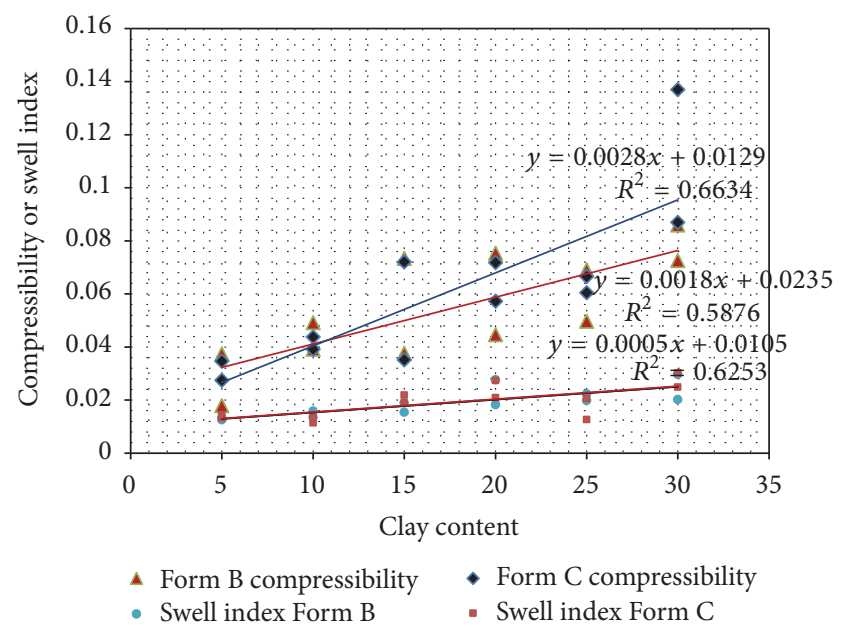

FIGURE 11: Compressibility and swell index for all tested clay ratios.

material is clearly reflected in the trend lines of both swelling pressure and swell percent.

5.5. Hydraulic Conductivity of Sand-Expansive Clay Mixtures. The hydraulic conductivity is a governing factor for the minimum clay content to be used. Al-Qatif clay-sand mixtures have been reported to give hydraulic conductivity values in the range of $7.20 \times 10^{-8} \mathrm{~cm} / \mathrm{s}$ for $5 \%$ clay and $3.54 \times$ $10^{-8} \mathrm{~cm} / \mathrm{s}$ for $25 \%$ clay at a surcharge pressure of $100 \mathrm{kPa}$ (Dafalla et al. 2013). The bentonite-sand mixture with $10 \%$ bentonite resulted in a hydraulic conductivity of $2.719 \times$ $10^{-6} \mathrm{~cm} / \mathrm{s}$ (Dafalla et al. 2013). It can be noted that Al-Qatif clay can perform better than commercial bentonite with regard to hydraulic conductivity. However, the advantage of the processed bentonite is the uniformity of properties unlike natural clay where you may encounter wide variations. This paper is concerned with the swell and compressibility behaviour of the mixtures and the hydraulic conductivity values quoted here are presented to demonstrate that the use of natural clay will not affect the liner basic requirements.

5.6. General Comments. Comparing the compressibility indices it can be seen that the addition of Al-Qatif clay to bentonite will result in reducing the compression index from 0.0986 to 0.0400 for $10 \%$ clay content and from 0.1883 to 0.05 for $15 \%$ clay content. This is equivalent to 60 and 70 percent for $10 \%$ and $15 \%$ clay, respectively.

The swelling pressure and swell percent are reduced significantly by adding Al-Qatif clay. The swelling pressure of bentonite-sand mixture of $15 \%$ clay is reduced from $200 \mathrm{kPa}$ to $100 \mathrm{kPa}$ and $185 \mathrm{kPa}$ for initially dry mixtures. The swell percent is reduced by nearly $50 \%$.

It can be seen that using bentonite alone may not be advisable due to the expected high swelling pressure and swell percent. The minimum clay ratio that will just satisfy the permeability required should be used. This is expected to be achieved using mixtures of bentonite and local natural clay of less expansion. From this study it seems that the use of $15 \%$ clay consisting of one-third bentonite is an appropriate choice for a clay liner with a hydraulic conductivity of 1 $\times 10^{-7} \mathrm{~cm} / \mathrm{s}$. Going for higher clay ratios will increase the compressibility and swelling of the liner material and this may result in problems for light structures or the general profile of the ground level.

\section{Conclusions}

The swell and compressibility behaviour of sand-expansive clay mixtures should be considered along with the other design requirements for liners. The appropriate clay ratio that satisfies the hydraulic conductivity and other factors should be selected in view of the swell and compression properties of the mixture. Local clay material of lower expansion properties can be considered as partial replacement for bentonite within the sand-clay mixtures. This study investigated adding AlQatif clay to commercial bentonite to compose a clay material with $1: 2$ and 2:1 Al-Qatif clay to bentonite ratios and then use it in sand-clay mixtures for liners.

It was found that addition of less expansive soil material to bentonite can reduce the compressibility by $60 \%$ to $70 \%$ for $10 \%$ and $15 \%$ clay content, respectively. The swelling pressure and swell percent were also found reduced significantly. Adding local less expansive natural clay to bentonite can produce liners that are less problematic with regard to expansion and settlement and should still be impervious enough to satisfy normal design requirements.

\section{Conflicts of Interest}

The author declares that they have no conflicts of interest.

\section{Acknowledgments}

The author would like to thank Tawasol Research Excellence Program (TRE Program), King Saud University, Riyadh, Saudi Arabia, for support. The author would like to thank Dr. Terry Cousens, University of Leeds, United Kingdom, for his valuable consultation and guidance for this study. Thanks also extend to Eng. Abdulsattar Al Qatt and Eng. Galal Fathelrahman for conducting most of the laboratory tests.

\section{References}

[1] D. E. Daniel, Geotechnical Practice for Waste Disposal, Chapman \& Hall, 1993.

[2] M. A. Dafalla and A. M. Al-Mahbashi, "Effect of adding natural clay on the water retention curve of sand-bentonite mixtures," in Unsaturated Soils: Research \& Applications, pp. 1017-1022, CRC Press, 2014.

[3] M. A. Dafalla, The use of the fall cone penetrometer in the characterization and assessment of swelling clays [Ph.D. thesis], University of Leeds, Leeds, UK, 2004.

[4] K. S. Katti, D. Sikdar, D. R. Katti, P. Ghosh, and D. Verma, "Molecular interactions in intercalated organically modified clay and clay-polycaprolactam nanocomposites: experiments and modeling," Polymer, vol. 47, no. 1, pp. 403-414, 2006.

[5] J. K. Mitchell, J. D. Bray, and R. A. Mitchell, "Material interactions in solid waste landfills," in Proceedings of the Specialty 
Conference on Geotechnical Practice in Waste Disposal, pp. 568590, New Orleans, La, USA, February 1995.

[6] S. E. Obrike, C. C. Osadebe, and S. S. Omoniyi, "Geotechnical analysis of two Nigerian soils for use as clay liners," Bulletin of Engineering Geology and the Environment, vol. 68, no. 3, pp. 417419, 2009.

[7] N. J. Langdon, M. J. Al Hussaini, P. J. Walden, and C. M. Sangha, "An assessment of permeability of clay liners: two case histories," Geological Society, vol. 11, pp. 291-297, 2008.

[8] "Standard test method for evaluation of hydraulic properties of geosynthetic clay liners permeated with potentially incompatible liquids. Annual book of ASTM Standards," Tech. Rep. ASTM D 6766-2012, ASTM, Philadelphia, Penn, USA, 2012.

[9] Y. Wasti and I. Alyanak, Kil Muhtevasının Zeminin Davranışına Tesiri. Inşaat Mühendisleri Odası, Türkiye İnşaat Mühendisliği 4. Teknik Kongresi, Ankara, Turkey, 1968.

[10] R. E. Olson and G. Mesri, "Mechanisms controlling the compressibility of clay," Journal of the Soil Mechanics and Foundations Division, A.S.C.E, vol. 96, pp. 863-1878, 1970.

[11] A. K. Mundegar, An investigation into the effects of platy mica particles on the behavior of sand [M.S. thesis], Imperial College, London, UK, 1997.

[12] P. V. Lade, C. D. Liggio Jr., and J. A. Yamamuro, "Effects of nonplastic fines on minimum and maximum void ratios of sand," Geotechnical Testing Journal, vol. 21, no. 4, pp. 336-347, 1998.

[13] S. Tsotsos, F. E. Karaoulanis, and T. Chatzigogos, "A new concept on the compressibility of mixed soils: experimental and numerical approach," Geotechnical and Geological Engineering, vol. 28, no. 2, pp. 199-207, 2010.

[14] M. A. Dafalla, "The influence of placement conditions on the swelling of variable clays," Geotechnical and Geological Engineering, vol. 30, no. 6, pp. 1311-1321, 2012.

[15] D. A. Dixon, "Porewater salinity and the development of swelling pressure in bentonite based buffer and backfill materials," Atomic Energy of Canada Limited. POSIVA Report 200004, Posiva Oy, Helsinki, Finland, 2000.

[16] H. A. Alawaji, "Swell and compressibility characteristics of sand-bentonite mixtures inundated with liquids," Applied Clay Science, vol. 15, no. 3-4, pp. 411-430, 1999.

[17] L. H. Mollins, D. I. Stewart, and T. W. Cousens, "Predicting the properties of bentonite-sand mixtures," Clay Minerals, vol. 31, no. 2, pp. 243-252, 1996.

[18] C. Benson and G. Boutwell, "Compaction conditions and scaledependent hydraulic conductivity of compacted clay liners," in Constructing and Controlling Compaction of Earth Fills, D. Shanklin, K. Rademacher, and J. Talbot, Eds., ASTM STP 1384, pp. 254-273, ASTM, 2000.

[19] B. R. Phanikumar, C. Amshumalini, and R. Karthika, "Swellconsolidation characteristics of artificial sand clay mixes," in Proceedings of the Indian Geotechnical Conference, Geotrendz, IGS Mumbai Chapter \& IIT Bombay, 2010.

[20] S. N. Abduljauwad, "Characteristics and chemical treatment of expansive clay in Al-Qatif, Saudi Arabia," International Journal of Rock Mechanics and Mining Sciences \& Geomechanics Abstracts, vol. 29, no. 4, pp. 226-236, 1992.

[21] S. Azam, S. N. Abduljauwad, N. A. Al-Shayea, and O. S. B. AlAmoudi, "Expansive characteristics of gypsiferous/anhydritic soil formations," Engineering Geology, vol. 51, no. 2, pp. 89-107, 1998.

[22] S. Azam, "Influence of mineralogy on swelling and consolidation of soils in eastern Saudi Arabia," Canadian Geotechnical Journal, vol. 40, no. 5, pp. 964-975, 2003.
[23] M. A. Shamrani, E. Mutaz, A. J. Puppala, and M. A. Dafalla, "Characterization of problematic expansive soils from mineralogical and swell ell characterization studies," in Proceedings of the GeoFlorida 2010: Advances in Analysis, Modeling and Design, pp. 793-903, West Palm Beach, Fla, USA, February 2010.

[24] ASTM D2487-11, Standard Practice for Classification of Soils for Engineering Purposes (Unified Soil Classification System), vol. 15.09 of Annual Book of ASTM Standards, ASTM, West Conshohocken, Pa, USA, 2012.

[25] ASTM D698-02 2012, Standard Test Methods for Laboratory Compaction Characteristics of Soil Using Standard Effort (12 $400 \mathrm{ft} \mathrm{lbf} / \mathrm{ft} 3\left(600 \mathrm{kN} \mathrm{m} / \mathrm{m}^{3}\right)$, vol. 15.09, Annual book of ASTM Standards, West Conshohocken, Pa, USA, 2012.

[26] "Standard test methods for one dimensional swell or settlement potential of cohesive soils. Annual book of ASTM Standards," Tech. Rep. ASTM D4546-96 2012, ASTM, Philadelphia, Penn, USA, 2012. 

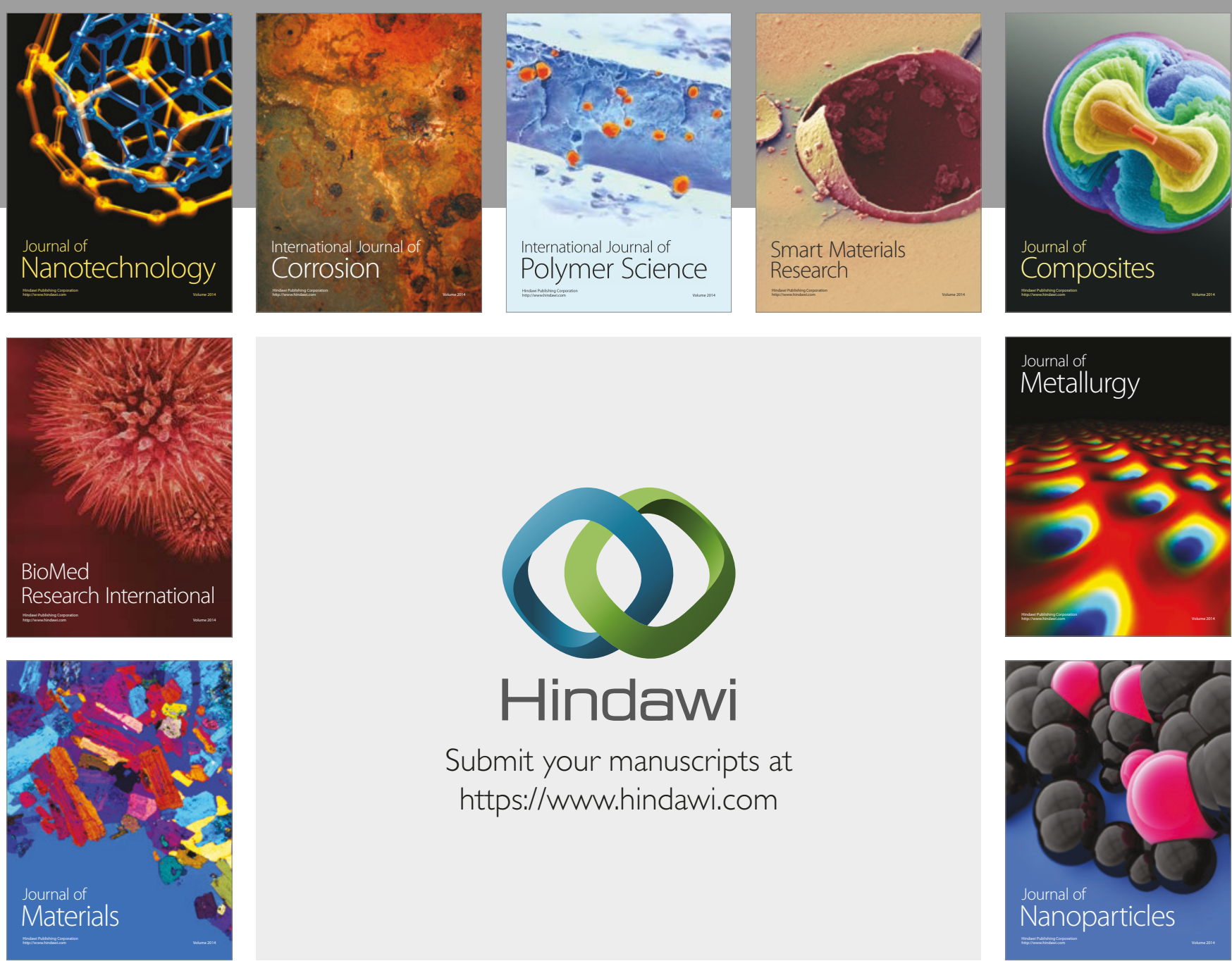

\section{Hindawi}

Submit your manuscripts at

https://www.hindawi.com
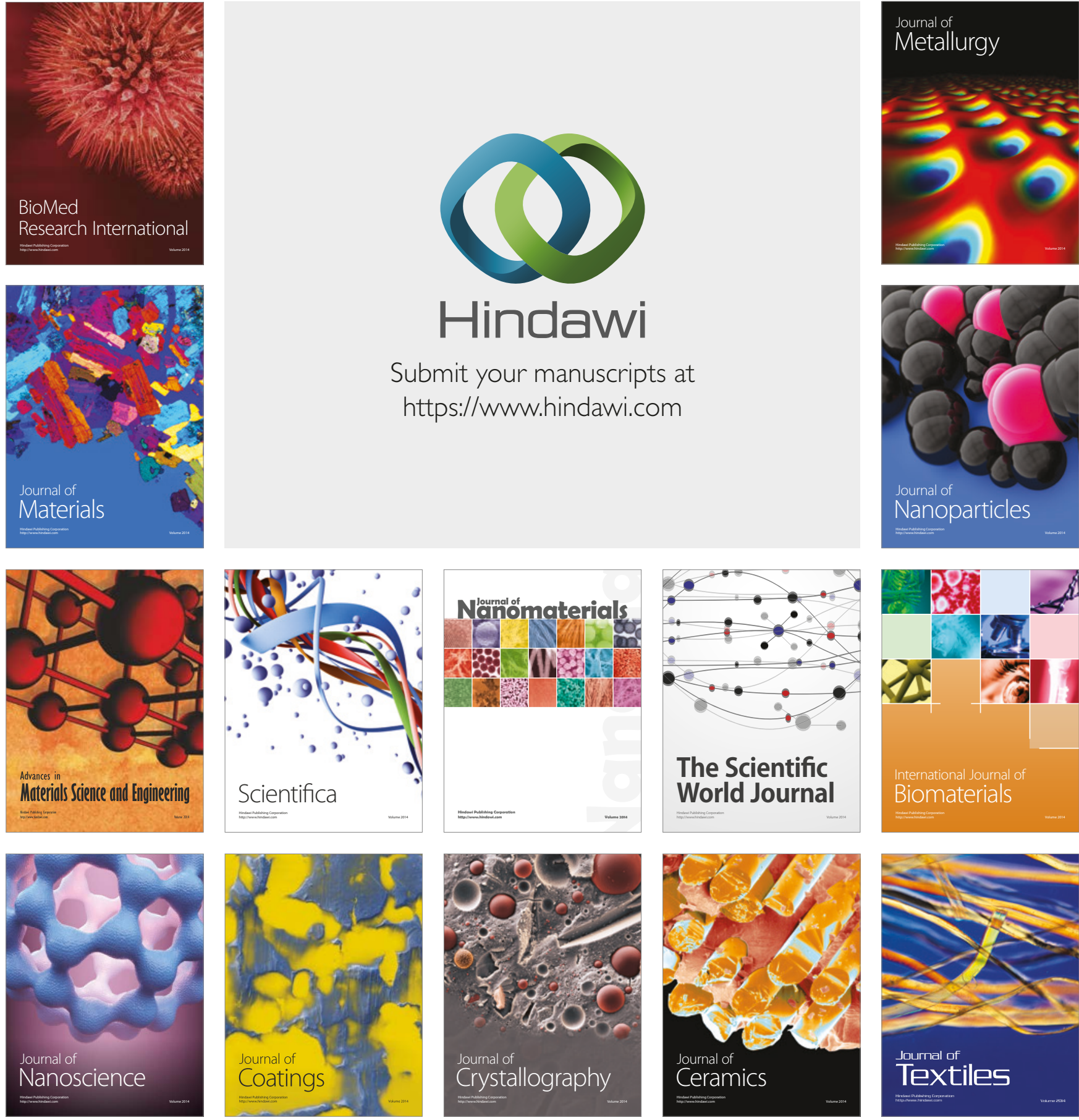

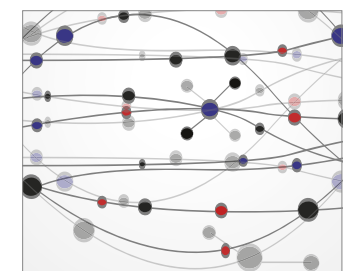

The Scientific World Journal
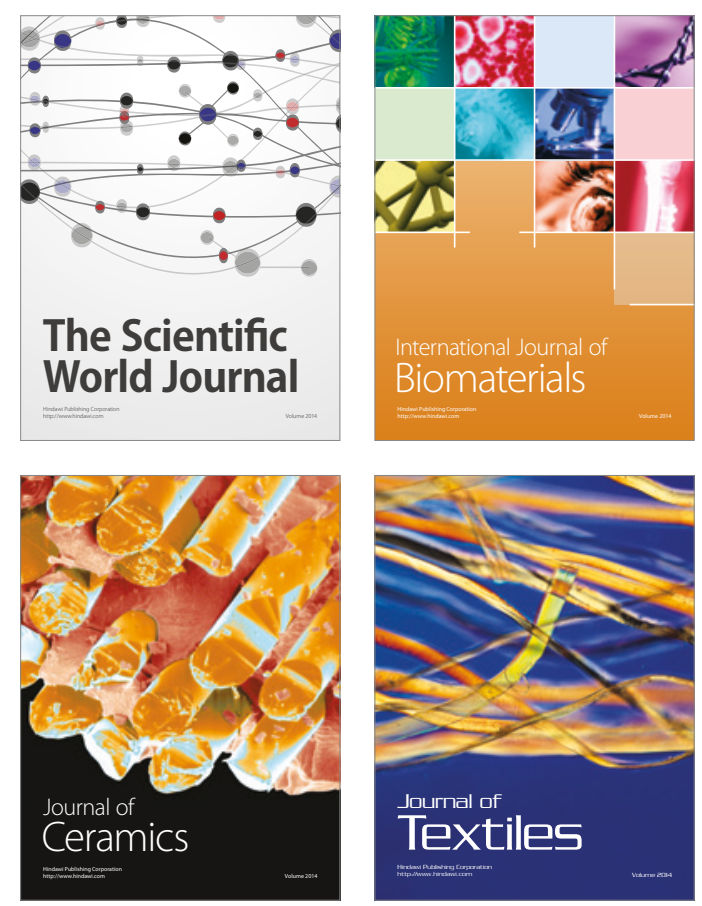